\title{
KOMUNIKASI TERAPEUTIK TERHADAP TINGKAT KECEMASAN PASIEN SEBELUM DILAKUKAN ANESTESI REGIONAL
}

\author{
Rio Verdiansyah, S.Pardosi, Gusnilawati \\ Politeknik Kesehatan Kementerian Kesehatan Bengkulu, Jurusan Keperawatan, \\ Jalan Indragiri Nomor 3 Padang Harapan Bengkulu \\ e-mail : rio_verdiansyah@yahoo.com
}

\begin{abstract}
The purpose of this study was to determine the effect of therapeutic communication to the patient's level of anxiety prior to regional anesthesia.

The type of research is the pre-experimental design using one-group pretest-posttest. Sampling techniques accidental sampling of 30 samples. Data analysis was performed using Univariate and Bivariate analysis with paired t-test test on a5\%.

The results showed that there were differences in the mean levels of anxiety before and after therapeutic communication and there is a significant decrease in the mean levels of anxiety before and after therapeutic communication. In patients before surgery with regional anesthesia in the operating room RSUD.Dr.M.Yunus Bengkulu ( $\mathrm{P}=0.000)$.
\end{abstract}

Key Words : Anxiety, Therapeutic Communication

\begin{abstract}
Abstrak : Tujuan penelitian ini adalah untuk mengetahui pengaruh komunikasi terapeutik terhadap tingkat kecemasan pasien sebelum dilakukan anestesi regional.

Jenis penelitian yang digunakan adalah pra eksperimental menggunakan desain one group pretestposttest. Teknik pengambilan sampel secara accidental sampling sebanyak 30 sampel. Analisis data dilakukan dengan menggunakan analisis Univariat dan Bivariat dengan uji paired t-test pada a5\%.

Hasil penelitian menunjukkan bahwa ada perbedaan rerata tingkat kecemasan sebelum dan sesudah dilakukan komunikasi terapeutik dan ada penurunan yang signifikan antara rerata tingkat kecemasan sebelum dan sesudah dilakukan komunikasi terapeutik. Pada pasien sebelum operasi dengan anestesi regional di kamar operasi RSUD.Dr.M.Yunus Bengkulu $(P=0,000)$.
\end{abstract}

Kata Kunci: Kecemasan, Komunikasi Terapeutik

Cemas merupakan hal yang sering terjadi dalam hidup manusia. Cemas juga dapat menjadi beban berat yang menyebabkan kehidupan individu tersebut selalu di bawah bayang-bayang kecemasan yang berkepanjangan dan mengaggap rasa cemas sebagai ketegangan mental yang di sertai dengan gangguan tubuh yang menyebabkan rasa tidak waspada terhadap ancaman, kecemasan berhubungan dengan stress fisiologis maupun psikologis. Artinya, cemas terjadi ketika seseorang terancam baik secara fisik maupun Psikologis (Asmadi, 2008).

Menurut Volicer \& Volicer yang dikutip oleh Rosintan pada tahun 2003, klien yang akan dilakukan pembedahan menunjukan stress yang tinggi dibandingkan dengan kelompok klien yang dirawat tanpa rencana tindakan pembedahan. Ketika kli- en tiba di ruangan operasi merupakan keadaan yang menambah kecemasan klien. Kecemasan yang mereka alami biasanya terkait dengan segala macam prosedur asing yang harus dijalani pasien dan juga ancaman terhadap keselamatan jiwa akibat segala macam prosedur pelaksanaan operasi dan tindakan pembiusan.

Berdasarkan laporan dari WHO (World Health Organization) tahun 2006 mencatat bahwa lebih dari 35.539 pasien bedah diseluruh dunia diantaranya 8.922 pasien $(25,1 \%)$ mengalami kondisi kejiwaan dan 2,473 pasien (7\%) mengalami gangguan kecemasan. Diperkirakan jumlah pasien yang mengalami gangguan kecemasan ini mencapai 5\% dari jumlah pasien, dengan perbandingan antara wanita dan pria 2 berbanding 1. Diperkirakan $2 \%-4 \%$ di antara pasien dalam 
kehidupannya pernah mengalami gangguan kecemasan (Hawari, 2006).

Data Operasi Indonesia Tahun 2007 dari 401 RSU (Rumah Sakit Umum) Depkes dan Pemda, operasi yang dilaksanakan sebanyak 642.632, yang dirinci menurut tingkat kelas A, B, C, dan D, data tersebut dikasifikasikan berdasarkan jenis operasi. Pada kelas A jumlah operasi besar adalah $8.364(16,2 \%)$, kelas B operasi besar 76.969 (19,8\%), pada kelas C jumlah operasi besar adalah 65.987 (34,0\%), pada kelas D jumlah operasi besar adalah 3.307 (41,0\%) (Depkes RI, 2007).

Banyak faktor yang mempengaruhi kecemasan pasien. Menurut Prof.Dr Dadang Hawari (2006) mekanisme terjadi cemas yaitu psikoneuro-imunologi atau psiko-neuro-endokrinolog, akan tetapi tidak semua orang yang mengalami stressor psikososial akan mengalami gangguan cemas hal ini tergantung pada struktur perkembangan keperibadian dari seseorang tersebut yaitu usia, tingkat pendidikan, pengalaman, jenis kelamin, dukungan sosial dari keluarga, teman, dan masyarakat.

Mengurangi kecemasan pasien adalah salah satu bentuk tugas untuk mengendalikan emosi pasien pre anestesi dan operasi, salah satu caranya adalah dengan menggunakan komunikasi terapeutik terhadap pasien, berupa penjelasan tentang prosedur tindakan agar pasien menjadi tenang dan cemasnya berkurang. Saat ini komunikasi terapeutik yang dilakukan oleh perawat hanya sebatas memenuhi tugas perawat tanpa mengenali sumber kecemasan dan hanya melakukan komunikasi sosial saja tetapi bukan melakukan komunikasi terapeutik sebagai terapi penyembuhan (Ellis dkk, 2001).

Banyak hal atau faktor yang bisa mengatasi kecemasan pada pasien sebelum dilakukan anestesi salah satunya dengan menggunakan komunikasi terapeutik. Komunikasi terapuetik adalah komunikasi yang di rencanakan secara sadar, bertujuan dan kegiatannya dipusatkan untuk kesembuhan pasien (Purwanto, 2003). Menurut Taylor (2002) menyatakan bahwa pembedahan adalah kerisis dalam kehidupan yang menyebabkan kecemasan. Perawat dapat mengurangi dan memeperbaiki kecemasan pasien dengan tindakan keperawatan difokuskan pada komunikasi terapeutik dan pendidikan kesehatan kepada pasien dan keluarganya.

Komunikasi perawat yang diarahkan pada pencapaian tujuan untuk penyembuhan pasien merupakan salah satu karakteristik komunikasi terapeutik. Kecemasan dapat dikurangi dengan tindakan keperawatan fokus pada komunikasi terapeutik bagi pasien dan keluarganya (Purwanto, 2003).

Berdasarkan data yang diperoleh dari Rekam Medik RSUD. M. Yunus Bengkulu jumlah pasien yang akan melakukan pembedahan pada Tahun 2010 berjumlah 2064 orang, rata-rata pasien yang akan menjalani pembedahan tiap bulannya berjumlah 94 orang. Dari data yang didapatkan 31 pasien $(32,6 \%)$ mengalami kecemasan ditandai dengan peningkatan tekanan darah, sedangakan 64 pasien $(67,3 \%)$ mengalami kecemasan ringan ditandai dengan kegelisahan, sedangkan jumlah pasien yang akan melakukan pembedahan tahun 2011 berjumlah 2671 orang, rata-rata pasien yang akan menjalani pembedahan tiap bulannya berjumlah 102 orang. Diantaranya 42 pasien $(41,1 \%)$ mengalami kecemasan yang ditandai dengan peningkatan tekanan darah, sedangkan 60 pasien $(58,8 \%)$ mengalami kecamasan ringan yang ditandai dengan kegelisahan. Sering kali terjadi penundaan pembedahan di RSUD $M$. Yunus Bengkulu karena pasien mengalami gejala kecemasan seperti hypertensi atau peningkatan tekanan darah. (sumber laporan tahunan instalasi bedah center).

Penelitian ini penting untuk mengetahui sejauh mana komunikasi terapeutik memberikan pengaruh pada penurunan tingkat kecemasan pasien sebelum dilakukan operasi dengan anestesi regional. Berdasarkan latar belakang di atas, masalah penelitian adalah tingginya tingkat kecemasan pasien sebelum dilakukan ko- 
munikasi terapeutik, maka rumusan masalah penelitiannya adalah "adakah pengaruh komunikasi terapeutik terhadap tingkat kecemasan pasien sebelum dilakukan anestesi regional di kamar operasi RSUD. Dr. M Yunus Bengkulu?."

Tujuan penelitian ini adalah diketahui pengaruh komunikasi terapeutik terhadap penurunan tingkat kecemasan pasien sebelum dilakukan anestesi regional.

\section{BAHAN DAN CARA KERJA}

Penelitian ini merupakan penelitian pra ekperimental dengan menggunakan desain one group pretest-postest. Populasi penelitian seluruh klien yang akan mendapatkan anastesi regional yang akan di lakukan operasi di RSUD Dr. M. Yunus Bengkulu dengan estimasi berdasarkan jumlah klien operasi dengan anastesi regonal tahun 2011 yaitu 2671 orang. Dalam penelitian ini sampel diambil meng- gunakan accidental sampling yaitu sampel yang menjadi objek penelitian adalah semua klien yang akan menjalani proses anestesi khususnya anestesi regional di kamar operasi RSUD Dr. M. Yunus Bengkulu Tahun 2013, dengan kriteria: bersedia menjadi sample penelitian, kooperatif /Sadar (CM), kriteria kecemasan ringan, dan sedang usia $>15$ tahun dan $<60$ tahun. Besar sampel adalah 30 orang. Analisa data yang dilakukan adalah analisa univariat dan bivariat dengan uji statistik paired T-Test.

\section{HASIL}

\section{Analisa Univariat}

Analisa univariat untuk melihat nilai mean, nilai minimal dan maksimal dan standar deviasi serta Coefidence Interval (CI) sebelum dan sesudah dilakukan komunikasi terapeutik.

Tabel 1. Distribusi Rata-rata Kecemasan Pasien Sebelum Dilakukan Anestesi Regional Sebelum dilakukan Tindakan Komunikasi Terapeutik di Instalasi Bedah Central (IBC)

\begin{tabular}{cccccc}
\hline Variabel & N & Mean median & SD & Minimal-maksimal & 95\%CI for mean \\
\hline Kecemasan sebelum komunikasi terapeutik & 30 & 23,17 & 3,141 & $14-29$ & $14,479-18.721$ \\
& & 23,00 & & & \\
\hline
\end{tabular}

Hasil didapatkan rata-rata kecemasan pasien sebelum dilakukan anestesi regional sebelum dilakukan tindakan komunikasi terapeutik adalah 23,17 dengan SD 3,141. Kecemasan pasien sebelum dilakukan anastesi regional sebelum dilakukan tindakan komunikasi terapeutik terkecil 14 dan tertinggi 29. Dari hasil estimasi interval dapat disimpulkan bahwa $90 \%$ diyakini rata-rata kecemasan pasien sebelum dilakukan anestesi regional sebelum dilakukan tindakan komunikasi terapeutik adalah diantara14,479-18,721.

Tabel 2. Distribusi Rata-Rata Kecemasan Pasien Sebelum dilakukan Anestesi Regional Sesudah Dilakukan Tindakan Komunikasi Terapeutik di Instalasi Bedah Center (IBC)

\begin{tabular}{lccccc}
\hline \multicolumn{1}{c}{ Variabel } & $\mathrm{N}$ & $\begin{array}{c}\text { Mean } \\
\text { Median }\end{array}$ & $\mathrm{SD}$ & $\begin{array}{c}\text { Minimal- } \\
\text { Maksimal }\end{array}$ & 95\% CI for mean \\
\hline $\begin{array}{l}\text { Kecemasan sesudah } \\
\text { komunikasi terapeutik }\end{array}$ & 30 & 5,57 & 1,040 & $3-8$ & $14,479-18,71$ \\
\hline
\end{tabular}

Hasil didapatkan rata-rata kecemasan pasien sebelum dilakukan anestesi regional sesudah dilakukan tindakan komunikasi terapeutik adalah 5,57, dengan SD 1,040. kecemasan pasien sebelum dilakukan anestesi regional sesudah dilakukan tindakan komunikasi terapeutik ter- kecil 3 dan tertinggi 8. Hasil estimasi interval dapat disimpulkan bahwa $90 \%$ diyakini rata-rata kecemasan pasien sebelum dilakukan anestesi regional sesudah dilakukan tindakan komunikasi terapeutik adalah 5,57-6,00. 


\section{Analisa Bivariat}

Analisis untuk mengetahui adanya penurunan kecemasan sebelum dilakukan tindakan komunikasi terapeutik dan se- sudah dilakukan tindakan komunikasi terapeutik, yaitu dengan menguji paired $t$ test pada $\propto 5 \%$ one tail (satu sisi), jadi ( $\propto$ x $2=10 \%$ ).

Tabel 3. Distribusi Rata-Rata Tingkat Kecemasan Responden Sebelum dan Sesudah Dilakukan Tindakan Komunikasi Terapeutik

\begin{tabular}{llccccc}
\hline \multicolumn{1}{c}{ Tingkat Kecemasan } & $\mathrm{N}$ & Mean & SD & SE & $\begin{array}{c}\mathrm{T} \\
(\mathrm{df})\end{array}$ & $\begin{array}{c}P \\
\text { Value }\end{array}$ \\
\hline Sebelum intervensi & 30 & 23,17 & 3,141 & 0,574 & 32,121 & 0,000 \\
& & & & & $(29)$ & \\
Sesudah intervensi & 30 & 5,57 & 1,040 & 0,190 & & \\
\hline
\end{tabular}

Rata-rata kecemasan pasien sebelum dilakukan anestesi regional sebelum dilakukan tindakan komunikasi terapeutik adalah 23,17 dengan standar deviasi 3,141, sedangkan rata-rata kecemasan pasien sebelum dilakukan anestesi regional setelah dilakukan tindakan komunikasi terapeutik adalah 5,57 dengan standar deviasi 1,140. terlihat nilai Mean mengalami penurunan setelah dilakukan tindakan komunikasi terapeutik adalah 5,57 dengan standar deviasi 1,040. hasil Uji Statistik menunjukan bahwa nilai $\mathrm{P}=0,000<10 \%$, Artinya ada penurunan rata-rata kecemasan pasien sebelum dilakukan anestasi regional setelah dibandingkan dengan sebelum dilakukan tindakan komunikasi terapeutik.

\section{PEMBAHASAN}

Gambaran Kecemasan Pasien Sebelum Dilakukan Anestesi Regional Sebelum dan Sesudah Dilakukan|Tindakan Komunikasi Terapeutik

Sebelum pelaksanaan perlakuan (intervensi) dengan tindakan komunikasi terapeutik untuk melihat pengaruhnya terhadap kecemasan pasien sebelum dilakukan anestesi regional dilakukan pengukuran pertama terhadap seluruh responden dengan menggunakan "Kuesioner Kecemasan Pasien Sebelum Dilakukan Anestesi Regional”.

Hasil penelitian didapatkan rata-rata kecemasan pasien sebelum dilakukan anastesi regional sebelum dilakukan tindakan komunikasi terapeutik 23,17 (95\% CI :
16,479-18,721). Sedangkan hasil analisis didapatkan rerata kecemasan pasien sebelum dilakukan anestesi regional sesudah dilakukan tindakan komunikasi terapeutik adalah 5,57 (95\% CI :16,479-18,721). Hal ini menunjukan bahwa setiap Pasien yang akan dilakukan tindakan operasi mengalami kecemasan dan ini sesuai dengan penelitian yang di lakukan oleh Makmur (2008) tentang kecemasan pre-operasi bahwa dari 40 orang responden memeiliki tingkat kecemasan berat sebanyak 7 orang $(17,5 \%), 16$ orang $(40 \%)$ masuk dalam katagori dalam keemasan sedang, 15 orang $(37,5 \%)$ masuk dalam katagori ringan, tidak memiliki rasa cemas 2 orang (5\%). Hasil penelitian makmur (2008) di rumah sakit otopedi prof. Dr. R. Soeharso menunjukan bahwadari 38270 pasien yang mengalami pembedahan sekitar $2 \%$ mengalami kecemasan. Rata-rata kecemasan sebelum dilakukan tindakan komunikasi terapeutik adalah 24,07 dan kecemasan sesudah dilakukan komunikasi terapeutik adalah 9.00. Hal tersebut juga menunjukan penurunan kecemasan pada semua responden. Hasil penelitian sejalan dengan Depkes (2002) bahwa salah satu cara yang dilakukan untuk kecemasan sebelum dilakukan anestesi regional adalah prawatan pre-operasi yang bertujuan mempersiapkan pasien anestesi regional secara fisik maupun mental. Apabila proses terganggu maka proses akan mengalami hambatan, adapun salah satu hambatan operasi di antaranya adalah kecemasan yang berlebihan pada pasien, sehingga efek anestesi kurang optimal. 
Penting menunjukan usaha yang diperlukan untuk mendapatkan hubungan perbedaan yang memastikan bahwa pasien akan benar-benar yakin akan alasan tindakan operasi serta hasil yang diharapkannya. Selain itu, pertimbangan tentang keluarga pasien dan perannya merupakan tanggung jawab utama lain bagi ahli bedah. Semua pernyataan pasien harus dijawab dengan lengkap untuk memberi keterangan penting sebanyak mungkin, menghilangkan kecemasan atau ketakutan pasien yang tidak tahu serta mengurangi kecemasan yang tidak tahu serta mengurangi kecemasan yang tidak perlu terhadap masalah yang mungkin tidak akan terjadi.

Perbedaan Rata-Rata Kecemasan Pasien Sebelum Dilakukan Anestesi Regional Sebelum dan Sesudah Dilakukan Tindakan Komunikasi Terapeutik

Hasil penelitian menunjukan rata-rata perbedaan kecemasan pasien sebelum dilakukan anestesi regional sebelum dan sesudah dilakukan tindakan komunikasi terapeutik adalah 17600 hasil penelitian juga menunjukan ada penurunan rata-rata penurunan kecemasan pasien sebelum dilakukan anestesi regional sesudah dibandingkan dengan sebelum dilakukan tindakan kominikasi terapeutik ( $p=0,000)$.

Keadaan ini menunjukan semua responden mengalami penurunan kecemasan sebelum dilakukan anastesi regional setelah dilakukan tindakan komunikasi terapeutik. Hal ini diperkuat dengan pendapat Ellis dkk (2001) bahwa menanggulangi dan menurunkan kecemasan pasien adalah salah satu tugas perawat, salah satunya dengan komunikasi terapeutik.

Hasil observasi selama penelitian responden yang mengalami kecemasan ditandai dengan beberapa hal diantaranya menjadi marah karena hal-hal kecil/sepele, mudah tersinggung,tidak tenang,mudah gelisa, ketakutan, sulit untuk beristirahat dan gangguan pola tidur,gangguan daya ingat, mulut terasa kering,kehilangan minta pada banyak hal, jantung berdebar-debar dan hipertensi mebutuhkan dukungan keluarga dan takut diri terhambat dari tugastugas yang tidak bisa terselesaikan.

Komunikasi perawat yang diarahkan pada pencapaian tujuan untuk menyembuhkan pasien merupakan salah satu karakteristik komunikasi terapeutik. Kecemasan dapat dikurangi dengan tindakan keperawatan yang fokus pada komunikasi terapeutik bagi pasien dan keluarganya sesuai dengan yang peneliti lakukan bahwa komunikasi terapeutik dapat mengurangi kecemasan. Keadaan ini sesuai dengan pendapat Kuntjoro (2002) yang menyatakan bahwa peran Perawat sangat penting dalam penanggulangan kecemasan dan berupaya agar pasien tidak merasa cemas melalui asuhan keperawatan yang komprehensif secara biologis, psikologis, sosial, dam spritual. Peran perawat sangat penting untuk memberikan suport atau dukungan dan penyuluhan terhadap penurunan tingkat kecemasan pada Pasien sebelum dilakukan tindakan operasi dan khususnya anestesi regional.

Penelitian ini sesuai dengan penelitian Setiawan (2002), yang menyatakan bahwa pelaksanaan komunikasi terapeutik memberikan efek yang signifikan terhadap penurunan tingkat kecemasan pada pasien pre operasi $(\mathrm{p}=0,014)$.

\section{KESIMPULAN}

Berdasarkan hasil penelitian dan pembahasan pengaruh komunikasi terapeutik terhadap penurunan kecemasan pasien sebelum dilakukan anastesi regional maka dapat dibuat kesimpulan sebagai berikut : Ada pengaruh yang signifikan pemberian komunikasi terapeutik terhadap tingkat kecemasan pada pasien sebelum dilakukan anastesi regional di kamar operasi RSUD Dr. M. Yunus Bengkulu tahun 2013 dengan $p$ value 0,000 .

Berdasarkan hasil penelitian dan pembahasan, penulis ingin memberikan saran kepada beberapa pihak terkait antara lain kepada bagi instansi RSUD. Dr. M. Yunus Bengkulu, sebaiknya dalam me- 
lakukan intervensi keperawatan selalu melakukan komunikasi terapeutik khususnya dalam menanggulangi dan mengurangi kecemasan pasien sebelum dilakukan anestesi regional sebagaimana tindakan operasi akan berjalan dengan baik, sebaiknya pada saat pasien sebelum dilakukan anestesi regional masuk ke ruang operasi perawat ruangan sebaiknya langsung memberikan komunikasi terapeutik kepada pasien tentang prosedur tindakan dengan melakukan komunikasi terapeutik yang baik, sebaiknya setiap breafing (pertemuan singkat) kepala ruangan selalu mengingatkan anggota tim untuk selalu menerapkan komunikasi terapeutik dan sebaiknya membuat prosedur tetap komunikasi terapeutik dalam pelaksanaan asuhan keperawatan khususnya pada pasien sebelum dilakukan anestesi regional.

\section{DAFTAR RUJUKAN}

Arikunto, S. 2010. prosedur penelitian suatu pendekatan praktis (edisi revisi VI). Jakarta:PT. Asdi Mahasatya

Davison, Naele, \& Kring. 2004. dalam http://www.psikologi.tarumanegara.ac.id .Diakses pada hari kamis , 01/11/2012.

Ellis dkk. 1999. Komunikasi Interpersonal Dalam Keperawatan (Edisi Terjemahan). Jakarta:EGC

Gunawan. 2008. Faktor - Faktor yang Berhubungan Dengan Kecemasan Pasien Pre Anestesi.Bengkulu.Tidak dipublikasikan.

Hawari. 2006. STRESS,CEMAS dan DEPRESI. Gaya Baru : Jakarta

Hidayah, Alimul .2007.metode penelitian kebidanan dan teknik analisis data.salemba medika;jakarta

Ikatan Dokter Indonesia. 2009. Engsiklopedi kedokteran. http.www.google.com

Kaplan. 1997. Synopsis psikiatrik. Jakarta : Binarupa Aksara

Kaplen, Harold I. 1998. Ilmu kedokteran jiwa darurat. Jakarta : widya medika

Kaplen. 1997. Synopsis psikiatri. Jakarta : Binarupa Aksara

Kasjono, S.H. 2009 Teknik Sampling Untuk Penelitian Kesehatan. Yogyakarta: Graha Permai

Keliat. 1996 hubungan terapeutik perawat klien. Jakarta. EGC
Saran bagi institusi pendidikan yaitu meningkatkan pendidikan tentang komunikasi terapeutik dan menekankan kepada mahasiswa untuk selalu menggunakan komunikasi terapeutik dalam praktek di instansi pelayanan kesahatan dan setiap berinteraksi dengan pasien sehingga pasien pelayanan khusunya pada pasien sebelum dilakukan anestesi regional.

Diharapkan kepada peniliti lain un-tuk dapat mengkaji faktor lain (pendidikan kesehatan, khayalan mental dan relaksasi) yang mempengaruhi kecemasan sebelum dilakukan anastesi regional. Peneltiannya dapat dilakukan dengan memperbanyak sampel yang di teliti dan menggunakan kelompok perbandingan, dan cara pengambilan sampel secara random sehingga didapatkan hasil yang lebih maksimal.

Laraia \& stuart. 1998. Principle and practice of psychiatric nursing Edisi 6 misouri:musby inc

Laraia \& Stuart. 1998. Principle And practice Of psychiatric NursingEdisi 6. Misouri: musby inc

Mangku, Senopati.2010.Ilmu Anestesia Dan Renimasi.indeks;Jakarta.

Nurjanah .2005. komunikasi keperawatan. Yogyakarta : moco medika

Nursalam. 2008. Konsep dan penerapan metodeologi penelitian ilmu keperawatan. Jakarta : salemba

Nursalam. 2008. Konsep Dan penetapan metodelogi Penelitian Ilmu keperawatan. Jakarta:Salemba

Albery,ian,dkk.2011.psikologi

kesehatan.yogyakarta:mitra setia.

Oswari. 2005. Bedah dan perawatanya. Jakarata: Gramedia pustaka utama

Saryono. 2010. Kumpulan istrumen penelitian kesehatan, bantul :kuha medika

Suart. Gail W.2007. Buku saku keperawatan jiwa.jakarta :EGC

Tailor C. 1997. Fundamental of nursing the art and acience of nursing care Edisi 3. Philadepia:Lippincolt Company

Uripin. C.L. 2003. komunikasi kebidanan. Jakarta:EGC 